\title{
Front Matter: Volume 6578
}

, "Front Matter: Volume 6578," Proc. SPIE 6578, Defense Transformation and Net-Centric Systems 2007, 657801 (22 May 2007); doi: 10.1117/12.741603

SPIE Event: Defense and Security Symposium, 2007, Orlando, Florida, United SPIE. States 


\section{PROCEEDINGS OF SPIE}

\section{Defense Transformation and Net-Centric Systems 2007}

\section{Raja Suresh}

Editor

9-12 April 2007

Orlando, Florida, USA

Sponsored and Published by

SPIE-The International Society for Optical Engineering

Volume 6578

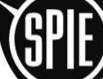


The papers included in this volume were part of the technical conference cited on the cover and title page. Papers were selected and subject to review by the editors and conference program committee. Some conference presentations may not be available for publication. The papers published in these proceedings reflect the work and thoughts of the authors and are published herein as submitted. The publisher is not responsible for the validity of the information or for any outcomes resulting from reliance thereon.

Please use the following format to cite material from this book:

Author(s), "Title of Paper," in Defense Transformation and Net-Centric Systems 2007, edited by Raja Suresh, Proceedings of SPIE Vol. 6578 (SPIE, Bellingham, WA, 2007) Article CID Number.

ISSN 0277-786X

ISBN 9780819467003

Published by

SPIE-The International Society for Optical Engineering

P.O. Box 10, Bellingham, Washington 98227-0010 USA

Telephone 1 360/676-3290 (Pacific Time) · Fax 1 360/647-1445

http://www.spie.org

Copyright @ 2007, The Society of Photo-Optical Instrumentation Engineers

Copying of material in this book for internal or personal use, or for the internal or personal use of specific clients, beyond the fair use provisions granted by the U.S. Copyright Law is authorized by SPIE subject to payment of copying fees. The Transactional Reporting Service base fee for this volume is $\$ 18.00$ per article (or portion thereof), which should be paid directly to the Copyright Clearance Center (CCC), 222 Rosewood Drive, Danvers, MA 01923. Payment may also be made electronically through CCC Online at http://www.copyright.com. Other copying for republication, resale, advertising or promotion, or any form of systematic or multiple reproduction of any material in this book is prohibited except with permission in writing from the publisher. The CCC fee code is 0277 $786 \times / 07 / \$ 18.00$.

Printed in the United States of America. 


\section{Contents}

ix Conference Committee

xi Introduction

NET-CENTRIC SYSTEMS, ARCHITECTURES, AND SERVICES

657802 Tactical service-oriented architecture over wireless communications [6578-01]

J. Gohde, P. Griffin, B. Rickenbach, General Dynamics Advanced Information Systems (USA)

657803 Testbed for large volume surveillance through distributed fusion and resource management [6578-02]

P. Valin, A. Guitouni, É. Bossé, Defence R\&D Canada/Valcartier (Canada); H. Wehn,

R. Yates, H. Zwick, MacDonald Dettwiler and Associates Ltd. (Canada)

657804 An evaluation of case-based classification to support automated web service discovery and brokering [6578-03]

R. Ladner, E. Warner, F. Petry, Naval Research Lab. (USA); K. M. Gupta, Knexus Research

Corp. (USA); D. W. Aha, Naval Research Lab. (USA)

657805 Enabling dynamic interoperability with multiple community of interest (COI) systems [6578-04]

A. Armbruster, E. J. Martens, D. E. Corman, The Boeing Co. (USA)

657806 An investigative analysis of information assurance issues associated with the GIG's P\&P architecture [6578-05]

B. S. Farroha, R. G. Cole, Johns Hopkins Univ. Applied Physics Lab. (USA); D. L. Farroha,

Defense Intelligence Agency (USA); A. DeSimone, OASD/NII (USA)

657807 Embedded instrumentation systems architecture [6578-06]

N. A. Visnevski, General Electric Global Research Ctr. (USA)

657808 Widely distributed C4ISR [6578-07]

D. A. Goughnour, S. D. Allen, M. J. Salonish, ElanTech, Inc. (USA)

Pagination: Proceedings of SPIE follow an e-First publication model, with papers published first online and then in print and on CD-ROM. Papers are published as they are submitted and meet publication criteria. A unique, consistent, permanent citation identifier (CID) number is assigned to each article at the time of the first publication. Utilization of CIDs allows articles to be fully citable as soon they are published online, and connects the same identifier to all online, print, and electronic versions of the publication.

SPIE uses a six-digit CID article numbering system in which:

- The first four digits correspond to the SPIE volume number.

- The last two digits indicate publication order within the volume using a Base 36 numbering system employing both numerals and letters. These two-number sets start with 00, 01, 02, 03, 04, 05, 06, 07, 08, 09, 0A, 0B ... 0Z, followed by 10-1Z, 20-2Z, etc.

The CID number appears on each page of the manuscript. The complete citation is used on the first page, and an abbreviated version on subsequent pages. 
657809 Measuring kill chain performance in complex environments [6578-08]

S. James, i-SAS Pty Ltd (Australia); A. Coutts, C. Stanford, F. Bowden, D. Bowley, Defence

Science and Technology Organisation (Australia)

INFORMATION MANAGEMENT ARCHITECTURES AND EXPERIMENTATION

65780A Evaluating technologies for tactical information management in net-centric systems [6578-09]

M. Xiong, J. Parsons, J. Edmondson, H. Nguyen, D. Schmidt, Vanderbilt Univ. (USA)

65780B Dynamic policy enforcement in JBI information management services with the KAoS policy and domain services [6578-10]

J. Donnelly, J. Madden, A. Roberts, M. Greenberg, Lockheed Martin Advanced

Technology Labs. (USA); J. Bradshaw, A. Uszok, Institute for Human and Machine Cognition (USA)

65780C A QoS management system for dynamically interoperating network-centric systems [6578-11]

J. P. Loyall, P. K. Sharma, M. Gillen, R. E. Schantz, BBN Technologies (USA)

65780D AIMS taking on roles to support tactical information dominance [6578-12]

P. J. Ceccio, Northrop Grumman Corp. (USA); R. G. Hillman, Air Force Research Lab. (USA)

65780F iFUSE: a development environment for composable easy-to-assemble information transforms [6578-14]

R. A. Joyce, J. P. Cormier, ATC-NY (USA)

$65780 G$ Semantic mediation and transformation services: perspectives on military application areas [6578-15]

J. R. Milligan, Air Force Research Lab. (USA)

$65780 \mathrm{H}$ Pedigree management and assessment in a net-centric environment [6578-16]

M. M. Gioioso, S. D. McCullough, J. P. Cormier, C. Marceau, R. A. Joyce, ATC-NY (USA)

65780I Composition modeling framework (CMF) [6578-17]

G. R. Staskevich, J. R. Milligan, T. A. Clark, Air Force Research Lab. (USA)

\section{SENSOR NETWORKS}

65780J Effectively networking unattended ground sensors (Invited Paper) [6578-18]

G. L. Duckworth, DARPA (USA)

65780K Methods for calculating the probability of detection and target location error of unattended ground sensors [6578-19]

K. W. Brendley, Artis, LLC (USA); G. Klager, CERDEC/NVESD (USA)

65780L A novel framework for command and control of networked sensor systems [6578-20]

G. Chen, Intelligent Automation, Inc. (USA); Z. Tian, Michigan Technological Univ. (USA);

D. Shen, Intelligent Automation, Inc. (USA); E. Blasch, K. Pham, Air Force Research Lab. (USA) 


\section{COMMUNICATIONS AND NETWORKS}

65780M Interference multiple access communications (Invited Paper) [6578-22]

L. R. Brothers, DARPA/STO (USA); J. A. DeBardelaben, Ivysys Technologies (USA);

J. Niedzwiecki, R. E. Learned, Y. Eisenberg, D. M. Cooper, BAE Systems (USA)

657800 Throughput of 802.11g wireless devices in ad hoc mode [6578-24]

B. B. LUU, R. L. Hardy, Army Research Lab. (USA)

65780P The airborne network definition project: a network architecture effort for future battlefield networks that enable network-centric warfare [6578-25]

B. Ganguly, S. Finn, J. McLamb, W. Bynoe, L. Veytser, I. Pedan, J. Mineweaser, S. Davidson, MIT Lincoln Lab. (USA)

65780Q Live-flight demonstration of agent technology for connecting the tactical edge to the global information grid [6578-26]

E. J. Martens, D. E. Corman, The Boeing Co. (USA)

65780R Demonstration of high-data-rate wavelength division multiplexed transmission over a 150km free space optical link [6578-27]

D. W. Young, J. E. Sluz, J. C. Juarez, M. B. Airola, R. M. Sova, H. Hurt, Johns Hopkins Univ. Applied Physics Lab. (USA); M. Northcott, J. Phillips, A. McClaren, D. Driver, D. Abelson, AOptix Technologies, Inc. (USA); J. Foshee, Air Force Research Lab. (USA)

657805 Long distance laser communications demonstration [6578-28]

M. J. Northcott, A. McClaren, J. E. Graves, J. Phillips, D. Driver, D. Abelson, AOptix Inc. (USA);

D. W. Young, J. E. Sluz, J. C. Juarez, M. B. Airola, R. M. Sova, H. Hurt, Johns Hopkins Univ.

Applied Physics Lab. (USA); J. Foshee, Air Force Research Lab. (USA)

65780T A framework for assessing and predicting network loads and performance for networkcentric operations and warfare [6578-29]

E. E. Santos, Virginia Polytechnic Institute and State Univ. (USA)

$65780 \mathrm{U}$ Synchronization for wireless multi-radar covert communication networks [6578-30]

S. C. Surender, R. M. Narayanan, Pennsylvania State Univ. (USA)

65780V A network-centric robust resource allocation strategy for unmanned systems: stability analysis [6578-32]

K. Bouyoucef, K. Khorasani, Concordia Univ. (Canada)

65780W Node compromise attacks and network connectivity [6578-33]

K. Chan, F. Fekri, Georgia Institute of Technology (USA)

SELF-ORGANIZING COLLABORATIVE ISR ROBOTIC TEAMS I: JOINT SESSION WITH CONFERENCE 6561

65780Y Multiplatform information-based sensor management: an inverted UAV demonstration [6578-35]

C. Kreucher, J. Wegrzyn, M. Beauvais, R. Conti, General Dynamics Michigan Research and Development Ctr. (USA) 
657810 Agent-based multi-plafform control, collaboration, and target hand-off [6578-37] N. Coleman, U.S. Army Armament Research, Development and Engineering Ctr. (USA);

B. Tirabassi, Technical Solutions Inc. (USA); D. MacKenzie, Mobile Intelligence Corp. (USA)

657811 Formation control in multi-player pursuit evasion game with superior evaders [6578-38] X. Wang, J. B. Cruz, Jr., The Ohio State Univ. (USA); G. Chen, Intelligent Automation Inc. (USA); K. Pham, E. Blasch, Air Force Research Lab. (USA)

657812 Collaborative multi-target tracking using networked micro-robotic vehicles [6578-39]

S. Biswas, S. Gupta, F. YU, T. Wu, Michigan State Univ. (USA)

657813 Hunter standoff killer team (HSKT) ground and flight test results [6578-40]

B. Moreland, M. Ennis, R. Yeates, T. Condon, Aviation Applied Technology Directorate (USA)

\section{Geolnt SYSTEMS}

657814 UrbanScape (Invited Paper) [6578-41]

B. Leininger, DARPA (USA); R. E. Nichols, SET Corp. (USA); C. Gragg, SAIC-GSTI (USA)

657816 Geospatial challenges in a net centric environment: actionable information technology, design, and implementation [6578-43]

M. R. Hieb, George Mason Univ. (USA); S. Mackay, Atmospheric and Environmental Research Inc. (USA); M. W. Powers, H. YU, U.S. Army Engineer Research and Development Ctr. (USA); M. Kleiner, J. M. Pullen, George Mason Univ. (USA)

657818 Orchestrating and optimizing multi-source ISR assets [6578-45]

M. G. Limcaco, General Dynamics AIS (USA)

\section{PREDICTIVE ANALYTIC MODELING}

65781 A Geographic information systems (GIS) approaches for geographic dynamics understanding and event prediction [6578-47]

M. Yuan, Univ. of Oklahoma (USA)

65781D Detecting space-time cancer clusters using residential histories [6578-50]

G. M. Jacquez, BioMedware, Inc. (USA) and The University of Michigan (USA); J. R. Meliker, BioMedware, Inc. (USA)

MDA SESSION

65781E GEOINT for MDA (Invited Paper) [6578-52]

C. Andreasen, C. H. Read, National Geospatial-Intelligence Agency (USA)

$65781 G \quad$ Maritime domain awareness community of interest net centric information sharing [6578-54]

M. Andress, Office of Naval Intelligence (USA); B. Freeman, The MITRE Corp. (USA);

T. Rhiddlehover, SOLERS (USA); J. Shea, PEO C4I, PMW 180 (USA) 
$65781 \mathrm{H}$ Determinants for global cargo analysis tools [6578-62]

M. Wilmoth, W. Kay, Office of Naval Intelligence (USA); C. Sessions, M. Hancock, Northrup Grumman/Essex (USA)

657811 Comprehensive maritime awareness (CMA) joint capabilities technology demonstration (JCTD) [6578-56]

C. Dwyer, Naval Research Lab. (USA)

$65781 \mathrm{~K}$ Automated detection of objects in sidescan sonar data [6578-58]

J. M. Irvine, S. A. Israel, S. Bergeron, SAIC (USA)

$65781 \mathrm{M}$ SeeCoast: persistent surveillance and automated scene understanding for ports and coastal areas [6578-60]

B. J. Rhodes, N. A. Bomberger, T. M. Freyman, W. Kreamer, L. Kirschner, A. C. L'Italien, W. Mungovan, C. Stauffer, L. Stolzar, A. M. Waxman, M. Seibert, BAE Systems, Advanced Information Technologies (USA)

Author Index 
Downloaded From: https://www.spiedigitallibrary.org/conference-proceedings-of-spie on 26 Apr 2023

Terms of Use: https://www.spiedigitallibrary.org/terms-of-use 


\title{
Conference Committee
}

\author{
Symposium Chair \\ John C. Carrano, Luminex Corporation (USA) \\ Symposium Cochair
}

Larry B. Stotts, DARPA (USA)

Program Track Chair

Raghuveer M. Rao, Rochester Institute of Technology (USA)

Conference Chair

Raja Suresh, General Dynamics Advanced Information Systems (USA)

Program Committee

John S. Eicke, Army Research Laboratory (USA)

Paul S. Gaertner, Defence Science and Technology Organisation

(Australia)

John W. Gowens II, Army Research Laboratory (USA)

Gayle D. Grant, U.S. Army Communications-Electronics Command (USA)

Robert G. Hillman, Air Force Research Laboratory (USA)

Michael A. Kolodny, Army Research Laboratory (USA)

John M. Pellegrino, Army Research Laboratory (USA)

Brian M. Sadler, Army Research Laboratory (USA)

Larry B. Stotts, DARPA (USA)

Guy Vézina, Defence R\&D Canada/Valcartier (Canada)

James Wood, Defence Science and Technology Laboratory

(United Kingdom)

\section{Session Chairs}

1 Net-Centric Systems, Architectures, and Services

Paul S. Gaertner, Defence Science and Technology Organisation

(Australia)

2 Information Management Architectures and Experimentation

Robert G. Hillman, Air Force Research Laboratory (USA)

3 Sensor Networks

Raja Suresh, General Dynamics Advanced Information Systems (USA)

Michael A. Kolodny, Army Research Laboratory (USA) 
John W. Gowens II, Army Research Laboratory (USA)

Gayle D. Grant, U.S. Army Communications-Electronics Command (USA)

$5 \quad$ Self-organizing Collaborative ISR Robotic Teams I: Joint Session with Conference 6561

Venkatarama Sundareswaran, Teledyne Scientific Company (USA)

George Vachtsevanos, Georgia Institute of Technology (USA)

Self-organizing Collaborative ISR Robotic Teams II: Joint Session with Conference 6561

Venkatarama Sundareswaran, Teledyne Scientific Company (USA)

George Vachtsevanos, Georgia Institute of Technology (USA)

7

Geolnt Systems

Beth H. Driver, National Geospatial-Intelligence Agency (USA)

8

Predictive Analytic Modeling

Beth H. Driver, National Geospatial-Intelligence Agency (USA)

9

MDA Session

Chung Hye Read, National Geospatial-Intelligence Agency (USA)

Michael Limcaco, General Dynamics Advanced Information Systems (USA) 


\section{Introduction}

These are the proceedings of the twelfth Defense Transformation and Net-Centric Systems conference. The papers presented at the conference strongly reflected the inexorable trend towards net-centric systems and service-oriented architectures. The conference included the following special sessions:

1. Self-organizing collaborative ISR robotic teams, held jointly with the Unmanned Systems Technology conference. Collaborative autonomous systems portend the increasing use of autonomic sensor and shooter platforms to perform the D3 (Dirty, Dull, and Dangerous) missions in an era of declining force structures.

2. Transformational geo-int systems. Actionable intelligence in now-time is increasingly being demanded by the warfighter in the GWOT. This will require a new way of thinking about national collectors and for creative means to marry national and tactical ISR to meet the warfighter's needs.

3. Maritime domain awareness (MDA). In the GWOT, a comprehensive awareness of the maritime domain is seen as being critical, as this mission transitions from the DoD to DHS. In the future, we plan to hold this session jointly with the Optics and Photonics in Global Homeland Security conference.

Invited speakers at the conference included Greg Duckworth (Foster-Miller), Chris Ramming (DARPA/STO), Brian Leininger (DARPA/IXO), and Amy Kruse (DARPA/DSO). We once again had excellent international participation with several papers being presented from Australia, Canada, and Germany, as well as the USA.

Looking ahead, we expect net-centric systems to be increasingly deployed in the field as C4ISR systems undergo their own "revolution." We expect to focus in the future on the networking of sensors and shooters from space to the mud, as well as distributed collaborative teams of robotic platforms.

It is gratifying to see the high level of audience interest in this conference. My sincere thanks to the distinguished invited speakers, authors, attendees, and my associates on the program committee for another successful conference.

Raja Suresh 
Downloaded From: https://www.spiedigitallibrary.org/conference-proceedings-of-spie on 26 Apr 2023

Terms of Use: https://www.spiedigitallibrary.org/terms-of-use 